\title{
The fluvial archive of the Middle and Lower Dnieper (a review)
}

\author{
A.V. Matoshko' ${ }^{1}$ P.F. Gozhik ${ }^{2}$ \& A.S. Ivchenko ${ }^{3}$
}

1 Corresponding author, Institute of Geological Sciences, National Academy of Sciences of Ukraine, 55B Gonchara Street, 01054, Kiev. Ukraine.

E-mail: matoshko@iptelecom.net.ua

2 P.F.Gozhik. Institute of Geological Sciences, National Academy of Sciences of Ukraine, 55B Gonchara Street, 01054, Kiev. Ukraine. E-mail: ignnanu@geolog.freenet.kiev.ua

${ }^{3}$ A.S.Ivchenko. Institute of Geography, National Academy of Sciences of Ukraine, 44, Volodymyrska Street, 01034, Kiev. Ukraine. E-mail: ivchenko@geogr.freenet.kiev.ua

Manuscript received: November 2000; accepted: January 2002

\begin{abstract}
Information about the morphology and alluvial sediments of the Dnieper Valley is reviewed. The Dnieper Valley originated in the Late Miocene. The Middle Dnieper Valley is an intercontinental alluvial basin and the Lower Dnieper Valley is a shallow canyon that ends with a delta. Identification of the alluvial dynamic facies (channel, overbank, abandoned channel) is crucial for stratigraphical analysis. The dynamic facies form regular sequences - alluvial suites that combine into series. Individual suites and series are characterized by their mode of occurrence, facies composition, lithological features and expression in the modern landscape. Their stratigraphic position is established with reference to index beds and palaeontological, geochronological and archaeological research, allowing them to be correlated along the valley. Correlation between different parts of the Dnieper system uses a combination of facies and geomorphological analyses, whereas correlation with other river systems makes use of mammalian and molluscan biostratigraphy. Global events (marine regressions and glaciations) that brought about similar reactions in different fluvial systems can be also used for correlation.
\end{abstract}

Keywords: alluvial deposits, Neogene, Quaternary, DnieperValley.

\section{Introduction}

The Dnieper River is one of the main waterways of the East European Plain. Its valley is infilled by Neogene Quaternary sediment, much of which is alluvial in origin. There is an immense body of information concerning the alluvium and valley morphology from the Dnieper, especially from the middle and lower parts of the valley. This constitutes one of the most complete fluvial archives, covering the time span from the Late Miocene to the present. Despite more than a century of investigations, elucidated in the publications of Dmitriev (1936), Zamoriy (1961), Goretskiy (1970), Volkov \& Sokolovskiy (1976) and Yes'kov (1977), there has been no systematic summary. Extensive data is available from geological surveys, exploration for water engineering construction and special works re- lating to river management over the last thirty years. The aims of this review are thus as follows:

- to systematize the available information;

- to discern and describe the various bodies of alluvial deposits and correlative landforms;

- to summarize and interpret the results of palaeontological research;

- to summarize the lithological data

- to correlate the fluvial formations of the Middle and Lower Dnieper valleys and determine their stratigraphic position;

- to set tasks for further investigations.

Descriptions of borehole records of the State Geological Depository, unpublished theses (Barshchevskiy, 1977; Gozhik, 1992), principal publications (cited below) and new research results form the basis of the review. 
There are two principal approaches to the study of fluvial formations of the Dnieper. The first is built upon the work of Goretskiy (1970), updated by adopting the theoretical principals of Shantser (1966), Lavrushyn (1966) and Reading (1986). The approach explores the complex nature of the alluvial sequences. Identification of alluvial dynamic facies (channel, overbank, abandoned channel) is key, based primarily on the lithological distinctiveness of the different alluvial bodies and their spatial variation. Each dynamic facies is lithologically uniform, representing specific palaeogeographical conditions of fluvial sedimentation. These facies are stacked vertically or grouped together laterally to form alluvial suites. Thus the notion of 'dynamic facies' is wider than that of 'lithofacies' (Miall, 1978; Reading, 1986). The suite reflects an elementary cycle of fluvial erosion and sedimentation. Suites of similar age and mutual relation (superimposed and cut-and-fill suites) combine to form series. All levels of this hierarchy can be accommodated within lithostratigraphic procedures.

The second approach, that of Veklich and Dubniak (1975), is based on the recognition of geomorphological terraces and determination of their stratigraphical position from the study of fossil soils in subaerial strata overlying the alluvial deposits. Clearly this second (indirect) approach can supplement the first.

The valleys of Middle and Lower Dnieper are considered separately as there are substantial differences in geological structure and local base-level (Dnieper rapids) between the two (Fig. 1). The Middle Dnieper valley occupies an intercontinental alluvial basin within the Dnieper-Donets'k Depression and the eastern slopes of the Ukrainian Shield. The Lower Dnieper Valley forms a shallow canyon crossing the Ukrainian Shield and following the incline of the South Ukrainian Monocline. The canyon structure is complicated by the small Zaporizhzhia-Nikopol' alluvial basin. Southeast of Kherson City, the Dnieper Valley merges with South Buh Valley and becomes wider, forming a delta. The fragmentary Dnieper fluvial formations can be traced on to the shelf of the Black Sea marine basin. It should be noted also that the two parts of the valley formed at different times.

\section{Structure of the Dnieper valley}

\section{The Middle DnieperValley}

The origin of the primary drainage pattern of the Middle Dnieper is associated with the final marine regression from north Ukraine, variously dated somewhere between the Middle Oligocene and the Miocene inclusive (Bondarchuk, 1975; Makarenko,
1987; Matsui et. al., 1993). The top of the Suite (Middle and Upper Miocene) has been taken as the initial surface on which the fluvial system developed. There is a great divergence of opinion on the nomenclature, age and occurrence of the oldest river terraces (Sobolev, 1938; Nazarenko, 1968; Sokolovskiy, 1973; Veklich \& Dubniak, 1975). A more precise age definition of the Novopetrov Suite, based on new data (Matsui et al., 1993), places the oldest alluvial deposits, which formed after the accumulation of the Novopetrov Suite, in the Upper Miocene - Pliocene Complex. In order to avoid confusion, in the present review some of suites and series have been given new stratigraphic names, whereas others retain their old names (See table 2).

\section{The Upper Miocene - Pliocene Complex}

Alluvial deposits of this complex are incised into plateau rocks of the Novopetrov Suite and are underlain mostly by sandy-clayey rocks of the Palaeogene and occasionally by Cretaceous rocks. The alluvial and overlying deposits formed in a valley cut into an inclined surface from a plateau at $170-150 \mathrm{~m}$ a.s.l., sloping westwards to $110-100 \mathrm{~m}$ a.s.l., where there is a scarp-like break of slope above the Quaternary river terraces to the west. Four series of deposits can be distinguished in the Upper Miocene - Pliocene Complex (thicknesses and facies compositions are given in Table 1.)

The Shostka Series, which comprises two superimposed suites, occupies the uppermost position within the valley. It is discerned only in left-bank Dnieper tributary valleys. Its base lies at an elevation of 136$148 \mathrm{~m}$ a.s.l. The Pyriatyn Series occurs in the same valleys but rather lower (121-128 $\mathrm{m}$ a.s.1.). Its base falls sharply to $115-117 \mathrm{~m}$ a.s.l. in the Middle Dnieper Valley and then gradually descends to the western flank of the Dnieper-Donets'k Depression (Figs 2 and 3). It can be assumed that the complex of Upper Miocene - Pliocene alluvial deposits in the Ros' Valley (Golubitskaya, 1973) corresponds with the Pyriatyn Series.

Numerous narrow incisions within the limits of the Pyriatyn Series have been established from boreholes (Fig. 3), some with an elongated curved erosional form (Fig. 2). The depth of the incisions, which have talwegs descending in a southern and southwestern direction, is $15-20 \mathrm{~m}$ on average and locally $40-45 \mathrm{~m}$ lower than the Pyriatyn Series. They are deepest in the main Dnieper Valley. The alluvium infilling these incisions is defined as the Parafiivka Series. Its maximum upper limit is several metres higher than the top of the Pyriatyn Series. It is assumed that the Parafiv$k a$ Series is the analogue of Venedian Suite, which was 


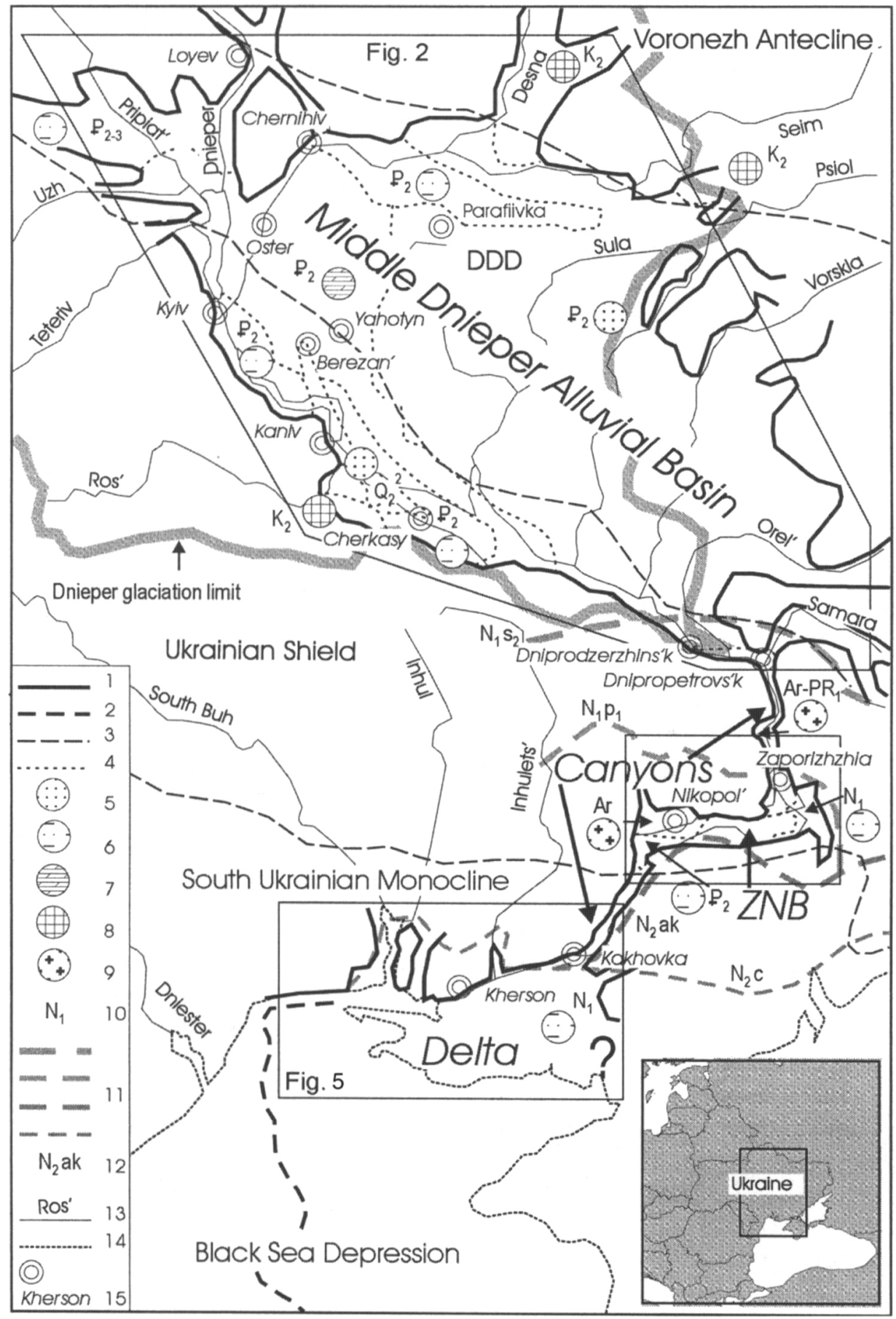

Fig. 1. Location map and geological map of the DnieperValley

1 - contours of the Valley (outer and south-eastern confines of the Delta are unknown); 2 - talweg of the Valley within the Black Sea shelf (presumably of Late Pleistocene age); 3 - boundaries between the main tectonic structures of the East European Platform; 4- boundaries between the areas of the different rock types of the valley-floor basement; 5-9 - types of the valley-floor basement rocks: 5 - sands, 6 - sands, silts, clays; 7-marls; 8 - chalk; 9 - igneous rocks; 10 - stratigraphical names; 11 - limits of the Neogene transgressions; 12 -ages of the transgressions; 13 - river pattern, including reservoirs, and river name; 14 - Black Sea and Azov Sea coastlines; 15 - cities, towns and their names. DDD - Dnieper-Donets'k Depression; ZNB - Zaporizhia-Nicopol' Basin.

Stratigraphic indices of the rocks: $\mathrm{Ar}$ - Archaean, $\mathrm{Ar}-\mathrm{Pt}_{1}-$ Archaean-Lower Proterozoic unstratified, $\mathrm{K}_{2}-\mathrm{Upper}_{\text {Cretaceous, }} \mathrm{P}_{2}-\mathrm{Eocene}_{2} \mathrm{P}_{2-3}$ - Eocene-Oligocene unstratified, $N_{1}-$ Miocene, $\mathbf{Q}_{2}{ }^{2}$ - upper half of the Middle Pleistocene.

Ages of the transgressions: $N_{1} s_{2}-$ Middle Sarmatian (Late Miocene); $N_{1} p_{1}-$ Early Pontian (Late Miocene), $N_{2} c-$ Cimmerian (Lower Pliocene), $\mathrm{N}_{2}$ ak - Akchaghylian (Upper Pliocene).

referred to the Lower Pleistocene by Goretskiy (1970). Otherwise it is necessary to invoke two maximum incisions of the Dnieper Valley in the Late
Miocene and Early Pleistocene at similar positions within the alluvial sequence. (Matviishina \& Vozgrin, 1991) have claimed, from palaeopedological data, a 
Table 1. Thickness and facies sequence of the alluvial series and suites. Compiled from Goretsky (1970), Barshchevsky (1977), Gozhick \& Novoselsky (1989), Matoshko \& Chugunny (1993) and new data in the possession of the authors.

Abbreviations: column 3: sev. - several, sup. - superimposed, c\&f. - cut- 8 -fill. column 4: facies names: b - basal, ch - channel, ach abandoned chanel, ob - overbank (flood-plain), ob-l - unstratified overbank and lacustrine, ob-ach - unstratified overbank and abandoned channel, pgl - specific 'periglacial' facies of glacier-fed rivers, lim-m - unstratified liman-marine; 1., 2. - different sections.

\begin{tabular}{|c|c|c|c|c|}
\hline Alluvial series (suites) & $\begin{array}{l}\text { Maximum } \\
\text { thickness } \\
\mathrm{m}\end{array}$ & $\begin{array}{l}\text { Number of } \\
\text { suites in series } \\
\text { and their } \\
\text { interrelation }\end{array}$ & $\begin{array}{l}\text { Dynamic facies } \\
\text { composition, relative } \\
\text { content of overbank } \\
\text { (overbank - lacustrine } \\
\text { facies) }\end{array}$ & Features \\
\hline 1 & 2 & 3 & 4 & 5 \\
\hline \multicolumn{5}{|l|}{ Middle Dnieper } \\
\hline \multicolumn{5}{|l|}{ Miocene-Pliocene complex } \\
\hline Shostka Series & $22-29$ & 2; sup. & ch, ob-ach & \\
\hline Pyriatyn Suite & $13-40$ & & $\mathrm{ch}, \mathrm{ob}-1(0.2-0.8)$ & \\
\hline Parafiivka Suite (Series) & $22-43$ & sev.; sup. & $\mathrm{ch}$ & \\
\hline Chornobyl' Series & $31-40$ & 2 ; sup. & $\mathrm{b}, \mathrm{ch}, \mathrm{ob}(0.2-0.3)$ & \\
\hline \multicolumn{5}{|l|}{ Quaternary Complex } \\
\hline Traktemyriv Series & $25-46$ & sev.; sup. & $\mathrm{b}, \mathrm{ch}, \mathrm{ob}, 1$ & \\
\hline Kryvych Series & $45-50$ & $2 ;$ sup. & $\mathrm{b}, \mathrm{ch}, \mathrm{ob}-\mathrm{l}(0.6-0.8)$ & $\begin{array}{l}\text { enriched by organic } \\
\text { remnants }\end{array}$ \\
\hline Hnidyn Suite & $24-71$ & & pgl, ob (0.1 and less) & \\
\hline Suite of the Second Terrace & $14-24$ & & $\begin{array}{l}\text { 1. - ch; } \\
\text { 2. - ch, ob }(0.2-0.3)\end{array}$ & \\
\hline Trypillia Suite & $12-31$ & & $\begin{array}{l}\text { 1. - b, ch, ob-ach }(0.4-0.6) \\
2 .-b, c h, o b(0.2-0.4)\end{array}$ & $\begin{array}{l}\text { syngenetic } \\
\text { polygonal ice-wedge } \\
\text { pseudomorphs }\end{array}$ \\
\hline Modern Suite & $8-22$ & & $\mathrm{~b}, \mathrm{ch}, \mathrm{ob}(0.1-0.3)$ & $\begin{array}{l}\text { enriched by organic } \\
\text { remnants, including } \\
\text { tree trunks }\end{array}$ \\
\hline \multicolumn{5}{|l|}{ Lower Dnieper } \\
\hline \multicolumn{5}{|l|}{ Pliocene Complex } \\
\hline Huinivka Series & $13-15$ & $2 ; \mathrm{c} \& \mathrm{f}$ & $\mathrm{ch}, \mathrm{ob}(0.3-0.5)$ & \\
\hline Parafiivka series & $\begin{array}{l}\text { reduced in all } \\
\text { sections }\end{array}$ & & $\mathrm{ch}$ & \\
\hline \multicolumn{5}{|l|}{ Quaternary Complex } \\
\hline Kairy Series & $13-40$ & 2 ; sup. & $\mathrm{b}, \mathrm{ch}, \mathrm{ob}(0.2-0.6)$ & \\
\hline Old Evksyn Series & $20-23$ & 2 ; sup. & $\mathrm{ch}, \lim -\mathrm{m}$ & \\
\hline Periglacial Series & $8-25$ & $2 ; c \& f$ & $\mathrm{pgl}$, ob & $\begin{array}{l}\text { lack of any organic } \\
\text { remnants }\end{array}$ \\
\hline Ochakiv Suite & $17-19$ & & $\begin{array}{l}\text { 1. }-\mathrm{ch} \\
\text { 2. }-\mathrm{b}, \mathrm{ch}\end{array}$ & \\
\hline Ant Suite & $24-26$ & & $\mathrm{~b}, \mathrm{ch}, \mathrm{ob}$ & \\
\hline Modern Suite & $4-12$ & & ch, ach, ob, & \\
\hline
\end{tabular}

Middle Pleistocene age for sediments in the deepest part of the incision near Parafiivka village. That is in conflict with the present interpretation, however.

The Chornobyl' Series is the youngest member of the Upper Miocene - Pliocene Complex within the interfluve between the Uzh and Prypiat' rivers (Fig. 2). Its base lies at $82-84 \mathrm{~m}$ a.s.1. The suite in the Vorskla Valley (Fig. 2, exposure 21) has a similar structure. Judging by some cross-sections in the lower course of the Orel' River, the Chornobyl' Series rests against the Pyriatyn Series with a lower base than the latter.

\section{The Quaternary Complex}

The updated work of Goretskiy (1970) is taken as the basis for analysing and reconstructing the Quaternary Complex. The Quaternary suites are mainly in the western part of the Dnieper Valley (Fig. 2) where they form a staircase of cut-and-fill terraces. They also represent a continuation of the Neogene cut-and-fill series. The hypsometric longitudinal profiles of the suites and corresponding terrace surfaces are represented in Fig. 4.

According to Goretskiy (1970), the oldest Quater- 


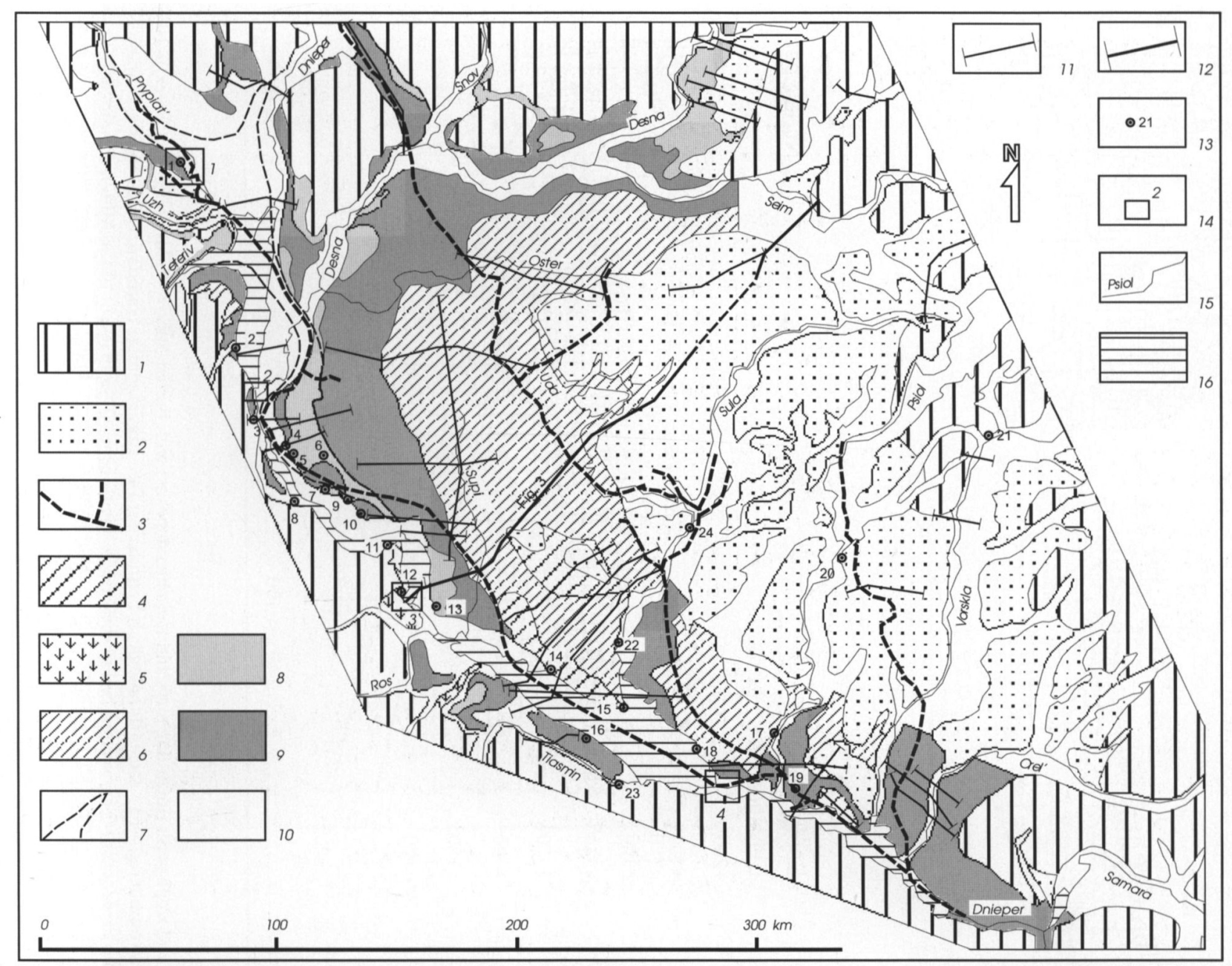

Fig. 2. Map of the alluvial suites and series distributions within the Middle DnieperValley

1 - plateau; 2 - Pyriatin Series; 3 - talweg of the maximum valley incision (presumably the end of the Late Miocene); 4 -Traktemyriv Series; 5 - glacial dislocations of the Dnieper horizon, including alluvial deposits of the Traktemyriv Series; 6 - Kryvych Series; 7 - contours of the Kryvych Series area beneath the younger alluvial series; 8 - Hnidyn Suite and Second terrace suite nonstratified; 9 - Trypillia Suite; 10 - Modern suite of the Dnieper, Prypiat' and Desna Valleys and also Quaternary unstratified alluvium of the tributary valleys; 11 - geological profiles (based on Veklich, 1968; Goretskiy, 1970; Barshchevskiy; 1977; Es'kov, 1977 and on new data); 12 - geological profile; 13 - main exposures of alluvium (numbered); 14 - boreholes (numbered); 15 - rivers (named); 16 - Dnieper reservoirs.

Main exposures: 1 - Pripiat's'kiy Zaton, 2 - Demidiv, 3 -Vitryani Hills, 4 -Vyrlitsa, 5 - Hnydin, 6 - Boryspil', 7 - Glyboke, 8 - Trypillia 2, 9 - Stare, 10 - Soshnykiv, 11 - Traktemyriv, 12 - Kaniv, 13 - Sushki, 14 - Mel'nycki, 15 - Zhovnyno, 16 - Borovitsa, 17 - Hun'ky, 18 Pyvykha Hill, 19 - Komsomol'sky open pit, 20 - Shishaki, 21 - Zarichne, 22 - Matviivka, 23 - Chyhyryn, 24 - Vyazovock.

Boreholes: 1 - Chornobyl' NPP neighboring zone, 2 - Vyshhorod, 3 - former Kaniv Power Station building site, 4 - Taburyshche (former Kremenchuh Power Station building site).

nary alluvial body is represented by the Venedian Suite, which is preserved in narrow incisions under the younger Pleistocene alluvium. As noted above, however, the Parafiivka Series and the Venedian Suite can be interpreted as a single Upper Miocene formation.

The Traktemyriv Series (= Fourth Terrace of Goretskiy (1970)) is highest within this complex (Fig. 2, exposures $3,11,14,15)$. Probable analogues of the Traktemyriv Series include Lower Pleistocene alluvial deposits in the Ros' Valley (Golubitskaya, 1973), the glacially dislocated alluvium of Pyvykha Hill (Gozhik, et al., 1976) and the Kaniv Hills (Lavrushyn \&
Chuhunnyi, 1982) and Middle Pleistocene alluvial deposits in the region of the Vitriani Hills in Kiev City (Barshchevskiy, 1977). It is overlain by the lacustrine Mel'nyki Suite. The deposits of the younger Kryvych Series (Fig. 3) have the widest distribution within the Quaternary Complex (Fig. 2).

The Postglacial Series includes four linked suites. Their deposits lie as a rule on the alluvium of the Kryvych and Venedian Suites and also on the meltwater deposits of the Shevchenko Suite (Dnieper Horizon) and, only rarely, on bedrock. Goretskiy (1970) and Yes'kov (1977) interpreted the Roslavl' and Trubizh suites as the oldest in this series but Matoshko 


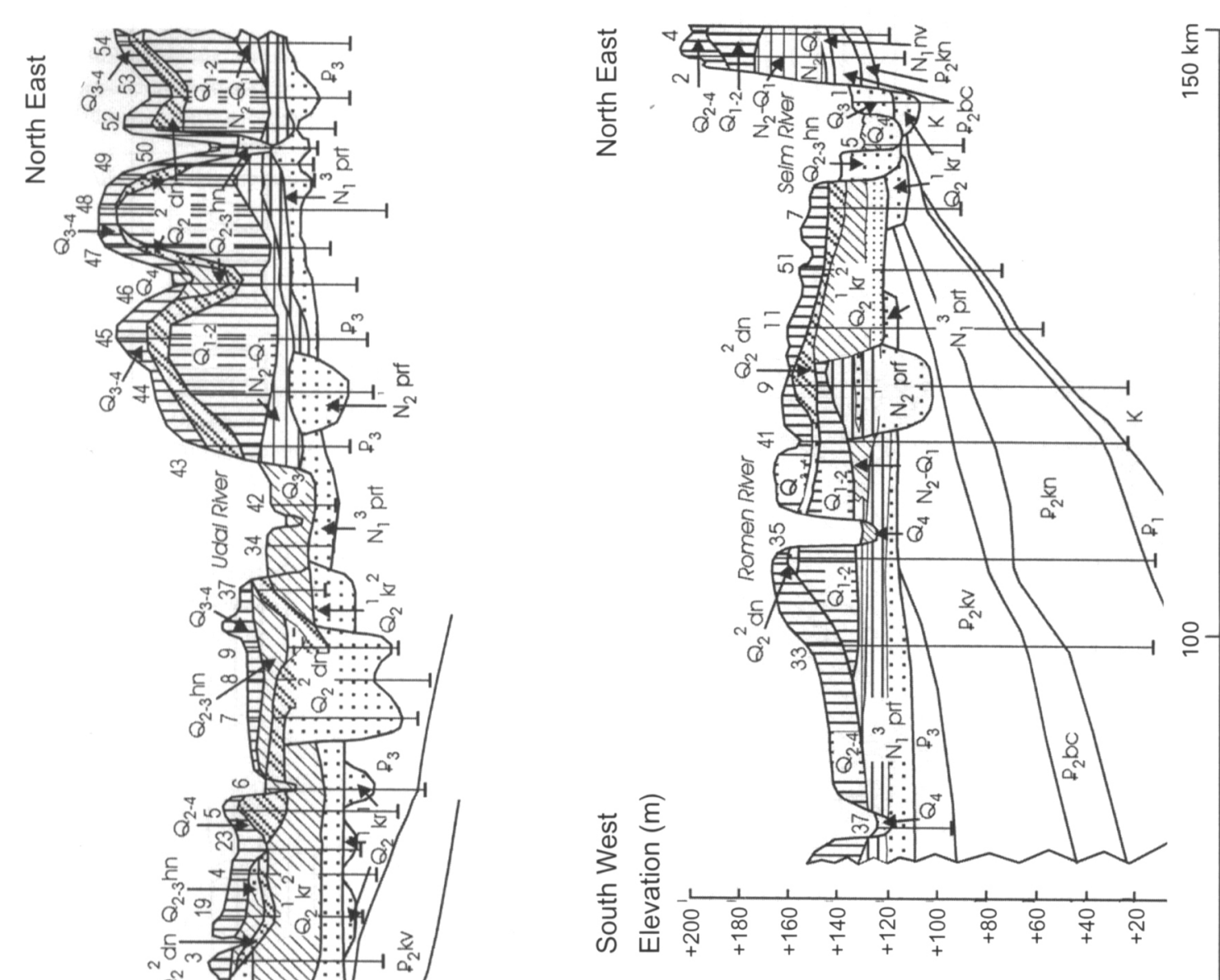

$\left.\begin{array}{l}E \\ \vdots \\ 0 \\ \stackrel{n}{n}\end{array}\right]$

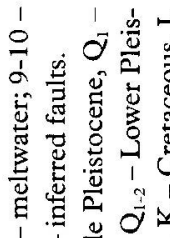

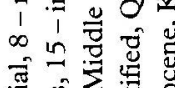
政

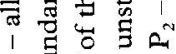
की है 要要营远 $\overrightarrow{0}$ है वे

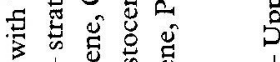

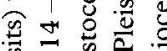

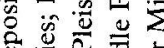

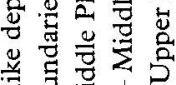

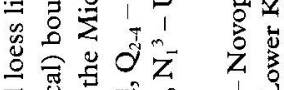

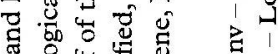

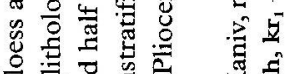
of ${ }_{0}$

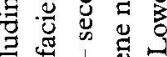
至起

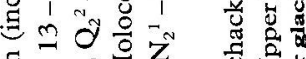

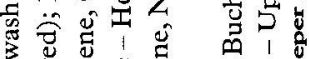

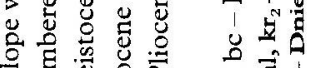

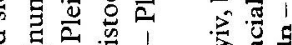

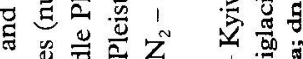

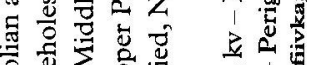

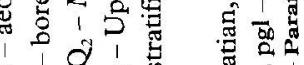
讨

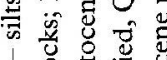
政

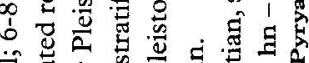

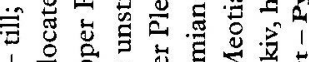

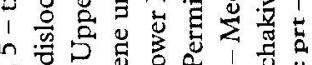

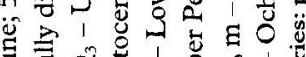

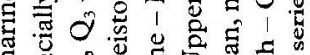

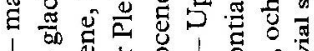
T.

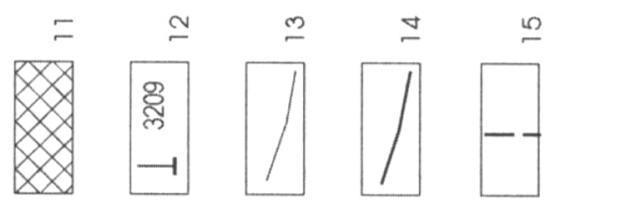

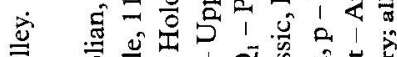

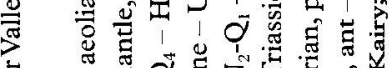

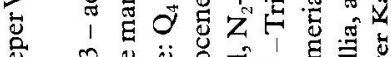

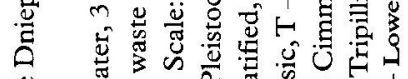

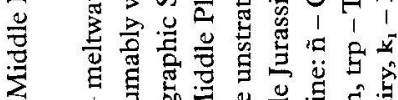

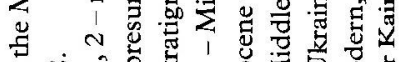

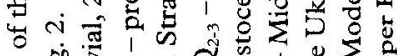

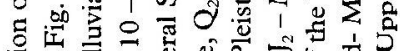

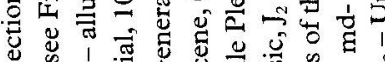

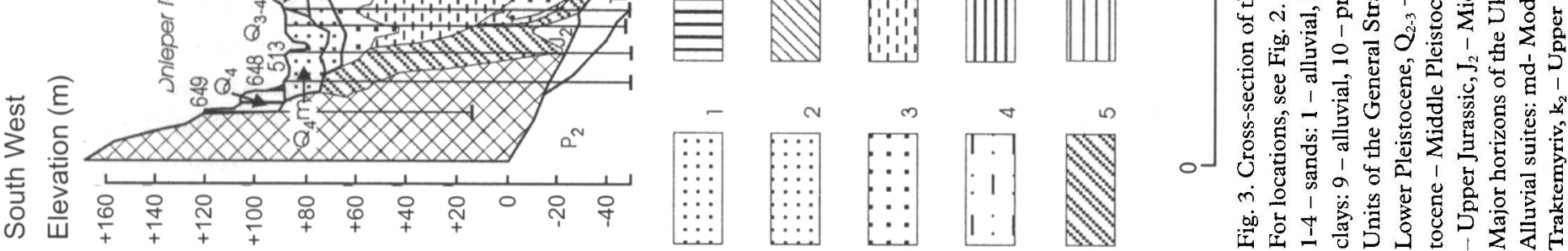


and Chuhynnyi (1993) regarded the Roslavl' Suite as the upper member of the Shevchenko Suite and the Trubizh Suite as the analogue of the Tripillia Suite within the basin of Trubizh River. Therefore the Hnidyn Suite (='Periglacial Suite', 'Suite of the Third Terrace') is considered to be the oldest postglacial alluvium. It occurs as broad gentle ridges (Matoshko \& Chuhynnyi, 1993). Goretskiy (1970) considered the deposits of this suite (Fig. 2, exposures 5, 7, 13; Fig. 3) to be 'periglacial' and thus dissimilar to the usual alluvial facies of temperate latitude rivers. The top of the Hnidyn Suite in many places lies higher than the top of the older Kryvych Series and also higher than the top of its glacial and subaerial cover. The alluvium of the Third Terrace of the Volga River (Goretskiy, 1966) and the so-called Voronezh fluvioglacial ridge of the Don River (Glushkov, 1985) share this unusual mode of occurrence and stratigraphical relations.

The Second Terrace Suite comprises small remnants of outwash, predominantly on the bedrock slopes of the Dnieper valley-side and also along the periphery of the Hnydin Suite area (Fig. 2). The largest strip of the Trypillia Suite (First Terrace Suite) lies between areas covered by the Kryvych Series and the Hnydin Suite (Fig. 2, exposures 8-10, 16). Smaller fragments of this suite occur near the valley mouths of Dnieper tributaries.

Present investigations have shown that the modern meander belt and the adjoining area of an older flood plain (the lower level of the first terrace above the flood plain (Matoshko, 1995)), share the similar alluvial characteristics that identify them as the single Modern Suite. Its largest outcrops occur near the confluences of the main tributaries (Fig. 2). There are two vast so-called internal fans near the confluence of the Prypiat', Dnieper and Desna rivers (Matoshko, 1995). Elsewhere the Modern Suite extends as a narrow strip along the river channel.

\section{The Lower DnieperValley}

\section{The Upper Miocene-Pliocene Complex}

The buried deposits of this complex are not expressed in the modern surface, their distribution being determined from boreholes and subsurface exposures. The oldest fluvial formations, occupying the highest hypsometric position (44-60 m a.s.l.), are the alluvial deposits of the superimposed Hunivka and Rogachick suites in the left bank area of the Lower DnieperValley (Fig. 6), initially dated as Pliocene (Moliavko, 1960). Gozhik considers that these suites were formed by the Dnieper after the regression of the Early Pontian Sea at the end of the Late Miocene and the beginning of the Pliocene. Ivchenko and Matoshko, however, at- tribute these suites to one of the left-bank Dnieper tributaries and believe they were formed either at the beginning of the stated regression, when the level of the Pontian Sea was still relatively high, or before the Late Pontian transgression. They argue that maximum incision of the Dnieper Valley (Figs $4 \& 5$ ) is reflected by the base of Venedian Suite (Goretskiy, 1970) or the Parafiivka Series (see above). These deposits are overlain by younger alluvium.

The Vasylivka Suite is referred to the Late Pliocene on the grounds of palaeopedological data (Veklich \& Sirenko, 1976). It was first recorded in the valley of the River Bazavluk, a right-bank Dnieper tributary, where its base is $27-32 \mathrm{~m}$ a.s.l. (Lepikash, 1938). Later it was described at Vasylivka (Fig. 6, exp. 31), where only its upper part is represented (Veklich \& Sirenko, 1976). Unstratified Pliocene alluvial deposits in the South Buh Valley (Fig. 6, exposures 32-36) are presumed to correlate with this suite.

\section{Quaternary Complex}

Alluvial deposits of this complex lie on Precambrian rocks in a canyon cut into the Ukrainian Shield, whereas elsewhere in the Lower Dnieper they overlie marine Upper Miocene rocks.

The Lower Pleistocene Kairy Series (= Kairy Suite of Goretskiy, 1970) forms the oldest part of this complex. It overlies mostly marine Neogene sediments and forms an extensive delta (Figs 4 and 6). Near the valley mouth it is expressed in the modern surface by a terrace with an upper surface at $25-40 \mathrm{~m}$ a.s.l. Next in the sequence, the Karai-Dubyna Suite (Fig. 6, exposure 29) of the second half of the Lower Pleistocene occurs at 7-9 m. The modern interpretation of the Nikopol' Suite (first described by Goretskiy (1970)) attributes it to right-bank tributaries of the Dnieper River (Fig. 6). The Old Evksyn Series, corresponding to the Kryvych Series of the Middle Dnieper, forms a buried delta in the mouth area (Figs 5 and 6). Its deposits overlap the alluvium of the Kairy Series and Parafiivka Series in some places, as well as Neogene and Lower Pleistocene marine sediments. The Periglacial Suite corresponds to the Hnydin Suite of the Middle Dnieper. Besides occurring in a small area near Nikopol' City, it is found near the mouth of the Dnieper (Figs 5 and 6). The Periglacial Suite predominantly overlies the deposits of the Old Evksyn and Kairy Series, forming a terrace with a surface at $10-20 \mathrm{~m}$ a.s.l. These deposits, presumably of Middle Pleistocene age, are known mainly from numerous offshore boreholes in Karkinit Bay, at depths greater than $30 \mathrm{~m}$ below sea level (Balandin \& Arbuzova, 1984).

The cut-and-fill Ochakiv and Ant Suites are promi- 


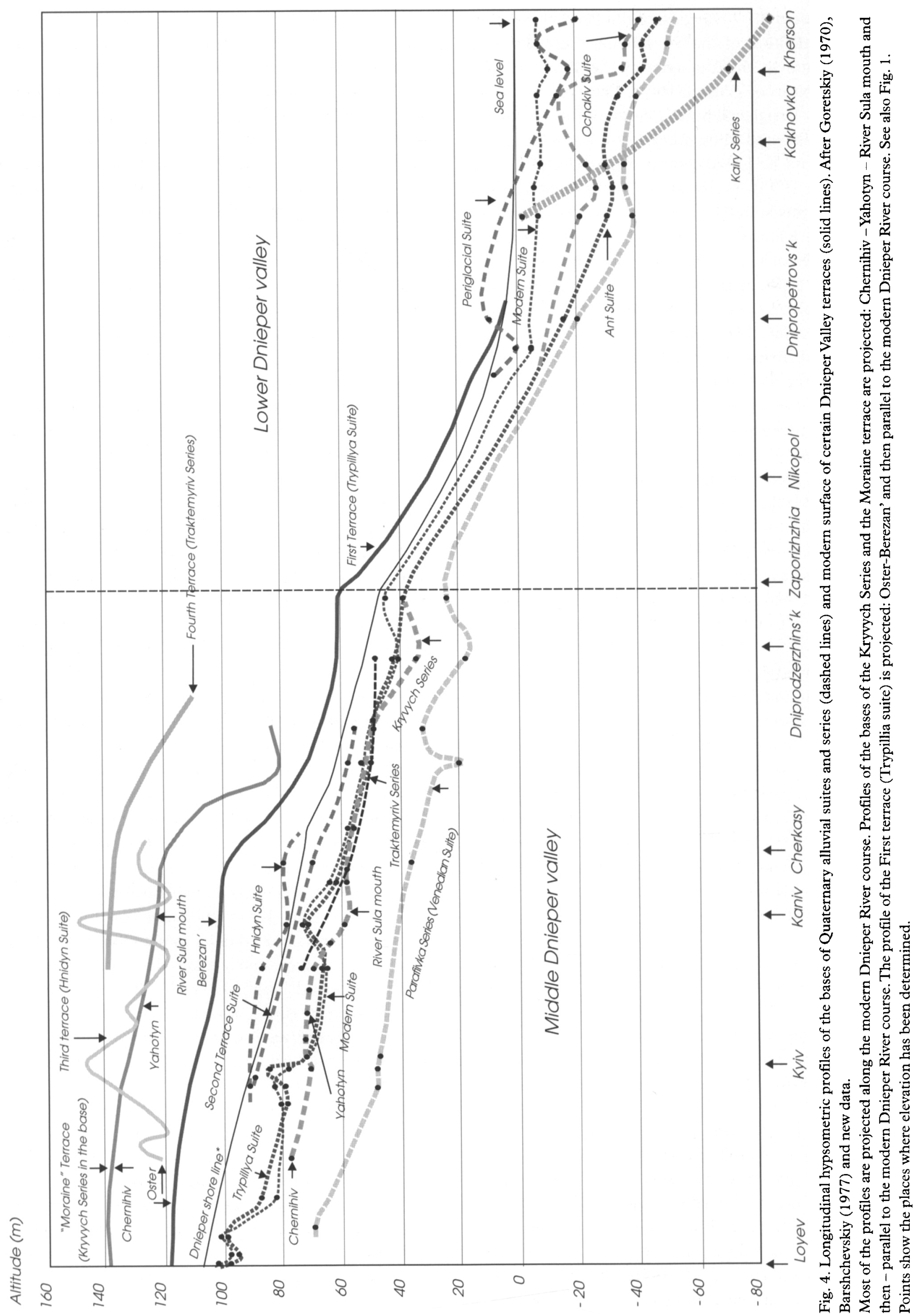


nent in the Lower Dnieper valley in the ZaporizhzhiaNicopol' region, where they form the Second and First terraces respectively. Towards the south the terraces disappear and the bases of the suites descend steeply (Fig. 4), so that within the Dnieper Liman and beneath the adjoining sea shelf these suites infill a deep incision (Fig. 5) associated with regression during the Last Glacial (Gozhik \& Kochubey, 1981; Gozhik \& Novosel'skiy, 1989). The sediments now referred to the Ochakiv and Ant suites were considered by Goretskiy (1970) to belong to the Kryvych Suite. These are incised into older Quaternary alluvial and marine deposits and are overlapped by Late Pleistocene marine and liman-marine sediments and also by the alluvium of the Modern Suite. This incision can probably be traced beneath the Black Sea to the shelf edge (Fig. 1).

The Modern Suite is poorly known. In the majority of the Lower Dnieper valley it is underlain by limanmarine silts of the New Evksyn transgression (end Late Pleistocene - Lower Holocene).

\section{Lithological characteristics of the alluvial deposits}

The majority of the alluvial suites are represented by channel facies (Table 1) consisting of fine-medium sands (74-88\%), usually dominated by fine sand (Fig. 7 ), but with silt lenses. Particle-size distribution, determined from 22 different key areas, has revealed no spatial trends. The amount of fine and coarse sand, as well as coarse material, increases in the Late Pleistocene and Holocene suites of the Lower Dnieper Valley in comparison with the suites of the Middle Dnieper Valley of the same age. Sections that were sampled in detail (at $0.2-1.0 \mathrm{~m}$ intervals) show a fining upwards trend. In other cases the particle-size distribution remains stable, although some suites at the top of superimposed series show a coarsening upwards.

The channel sands comprise $93-99 \%$ quartz and $1-7 \%$ feldspar, which is notably lower than in Upper Pleistocene - Holocene suites of the Upper Dnieper Valley (Motuz, 1972). In the Hnidyn Suite, the formation of which is associated with the Dnieper Glaciation, the percentage of quartz decreases to $88 \%$ and feldspar rises to $11 \%$. This can be explained by the influx of far-travelled glacial material from northern sources. Heavy mineral analysis of the fine sand fraction in the various series shows the following patterns. The Pliocene Chornobyl' Series (Fig. 2, exposure 21 ) is characterized by a disthene-sillimanite assemblage ( $>50 \%$ of heavy fraction). The Traktemyriv Series is characterized by a uniform ilmenite assemblage, whereas an ilmenite-garnet assemblage with increased representation of the amphibole group dominates in the other Quaternary series and is especially distinct in the Hnidyn and Modern suites. In comparison with the Upper Dnieper Valley (Motuz, 1972), the Upper Pleistocene suites of the Middle Dnieper Valley contain fewer unstable minerals and in the Middle Pleistocene suites of the Lower Dnieper Valley the ilmenite-garnet assemblage is supplemented by disthene-sillimanite and staurolite (Gozhik \& Novosel'skiy, 1989; Balandin, 1991). Lazarenko (1964) has shown that the mineralogical composition of the Modern Suite from Kiev to the mouth of the Dnieper changes little.

In respect to sedimentary structures, the channel sands display poorly developed or thin (average 2-5 $\mathrm{cm}$ ) horizontal-lamination (Fig. 2, exposures 2, 3, 8$10,14,15)$ with ripple-marks sometimes distinguishable. Several suites included cross-bedded sediments (Mel'nyk, 1928; Gozhik et al., 1976; Yes'kov, 1983; Fig. 2, exposures 11, 12, 16-19).

A basal facies is often distinguished within channel sequences, occurring locally in erosional scours or forming extensive sheets. In comparison with the channel alluvium, it contains increased amounts of silt-clay and coarse fractions and also material derived from the underlying rocks and deposits. In places it is gravelly, with boulders, clay rolls, mamallian bones, tree trunks and organic-rich lenses. The basal facies is generally cross-bedded.

An overbank (flood plain) facies forms the upper part of alluvial suites. In the Neogene series they have a high percentage of clay $(87.5 \%$ ), with silt at $9.5 \%$. Silts dominate in the Quaternary Complex, in which clays occur rarely. The clay fraction of the Pliocene lacustrine-alluvial deposits is dominated by montmorillonite (Vorona, 1969).

The Neogene clays are massive, with unclear lamination or without sedimentary structures. They often include carbonate or ferruginous-manganese concretions. In contrast, the overbank deposits of the Quaternary suites are characterized by horizontally laminated silts and interlaminated silts and clayey sands graded downwards to the channel facies. Crosslaminated levee deposits and also thin laminated deposits with humus and peat lenses of inter-levee depressions can be distinguished in the Modern Suite. The abandoned channel facies occurs locally as large lens-like bodies that represent the pattern of ancient channels in plan. They comprise interbedded horizontally laminated sands and silts enriched by organic matter and peat. Their clay fraction is represented by hydromicas and minerals of the montmorillonitekaolinite group in various proportions (Barshchevskiy, 1977). 


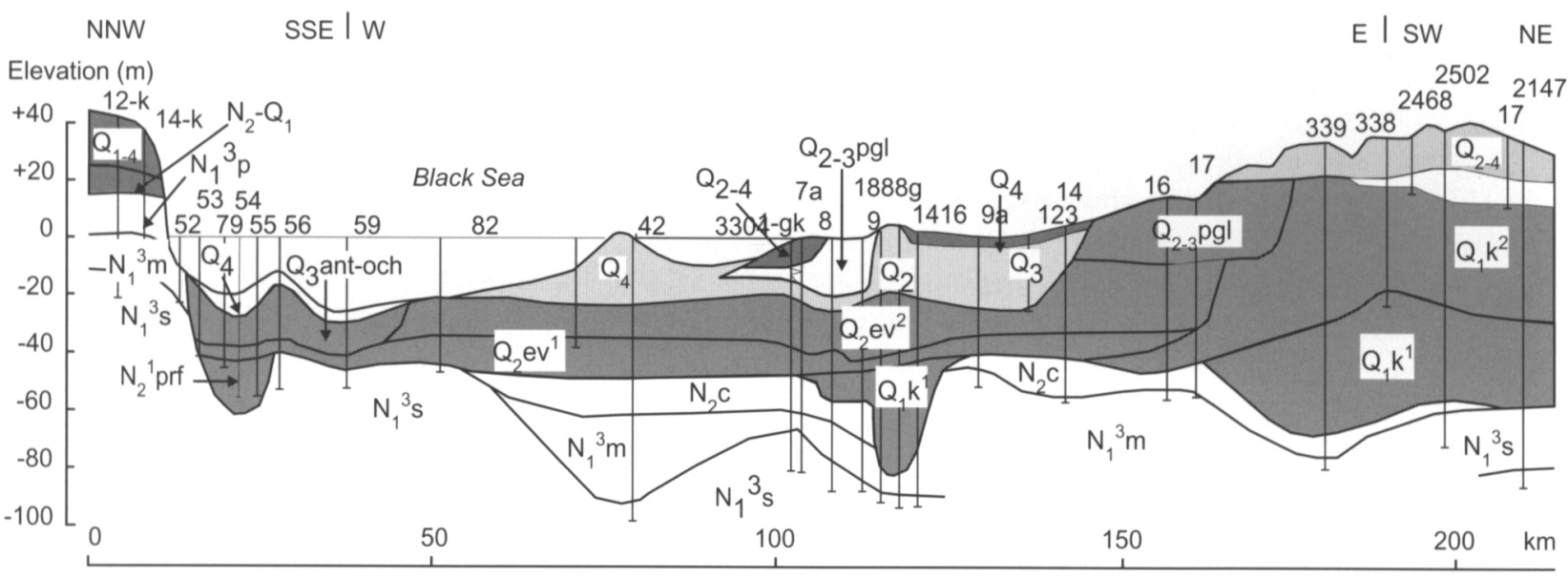

Fig. 5. Cross-section of the Lower Dnieper Valley.

For locations, see Fig. 6. For key, see Fig. 3.

Incorporates the work of Goretskiy (1970). The data of the Venedian Suite are referred to the Parafiivka Series.

The Hnydin and Periglacial Suites have distinctive sedimentary structures (Fig. 2, exposures 5, 7, 9, 13.). The upper part of the Hnydin Suite consists of uniform thin sets of low-angle cross-bedded sands, sometimes with ripple-laminated lenses. In some places cross-bedding is replaced by horizontal lamination, including varves. Horizontal and wavy lamination are characteristic of the deposits of the Periglacial Suite in the Lower Dnieper Valley (Goretskiy, 1970). In exposures of this suite, Goretskiy recorded chaotic alternations of members and lenses of sands and silts, often including carbonate, but without organic remains (Fig. 6, exposure 25).

\section{Stratigraphic position and correlation of alluvial deposits}

The stratigraphic position of the identified suites and series (Table 2) is established with reference to index beds and to palaeontological, geochronological and archaeological evidence.

The lower stratigraphical boundary of alluvial strata is placed tentatively at the top of the Lower Miocene Novepetrov Suite. There are no cogent arguments about the origin of this suite - continental or marine. Different points of view existed including its alluvial genesis (Nazarenko, 1968). The index horizon of reddish-brown clays and silts overlaps the alluvial deposits of the Upper Miocene-Lower Pleistocene and equivalent marine sediments, the age of which is determined from their fauna. The glacial deposits of the Dnieper Horizon, correlated with glacial deposits of the Odra and Saale glaciations of Central and Western Europe (Matoshko \& Chuhunnyi, 1993), and the alluvium of the Hnydin and Periglacial suites serve as regional reference points for the Quaternary Complex. These formations are referred to the sec- ond half of the Middle Pleistocene. The New Evksyn Horizon of marine-liman mud and silts is the local index bed for the area around the mouth of the Dnieper.

The Quaternary alluvium can be clearly separated from the Neogene fluvial deposits by evidence from mammalian faunal remnants contained in it and their allocation to the main faunal complexes of the Pleistocene: the Tamanian, Tyraspol', Singil', Hazarian and Upper Palaeolithic complexes (Table 3). The location of sites with faunal remains are shown in Figure 2 (exposures 12, 17, 22, 23, detailed area 2, 3) and Figure 5 (exposures 25-30, detailed area 5). Of particular value is the study of small mammal remains. Several faunal complexes (predominantly Rodentia as well as Insectivora and Lagomorfa) are distinguished in the alluvial series of the Early and Middle Pleistocene (Rekovets, 1994), while evidence from molluscs is a further important stratigraphical tool (Gozhik, 1992). These have been especially effective for establishing the stratigraphical sequence and for the correlation of alluvial and marine-liman deposits in the area near the mouth of the Dnieper.

The rich faunal assemblages in the Dnieper alluvium, providing data that forms the basis of correlation with well studied assemblages from the Dniester valley (Gozhik, 1992). The most ancient large and small mammal assemblages have been discovered in the alluvium of the Eopleistocene Kairy Suite (Fig. 6, exposure 30), which belong to the Tamanian faunal assemblage. This assemblage is typified by remains of Elephas merodionalis and Equus stenonis. The small mammals Prolagurus pannonicus, Allophaiomys pliocaenicus, Spermophilus nogaici and Mimomys intermedius characterize the Nogayian subassemblage of the Tamanian assemblage. They are correlated with 
Table 2 Correlation between Middle Dnieper valley, Low Dnieper valley and Azov-Black Sea Basin oscillations during Upper Miocene, Pliocene and Quaternary.

The positions of the Huinivka and Rogachick suites are cited according to P.F.Gozhik's ideas.

Abridgments: St. - suite, Sr. - series; T - transgression; R - regression; S - stable sea level (oscillations are not more than $10 \mathrm{~m}$ ); MD - Middle Dnieper; LD - Lower Dnieper; accum. - accumulation;

Postglacial Series combines suites that originated after the Dnieper Glaciation

* - according to the Stratigraphic Code of the Ukraine (Teslenko, 1997);

$\star \star$ - correlation between Azov-Black Sea and Mediterranean Basin is cited according to Semenenko (1993);

$\star \star \star$ - data by Semenenko (1993).

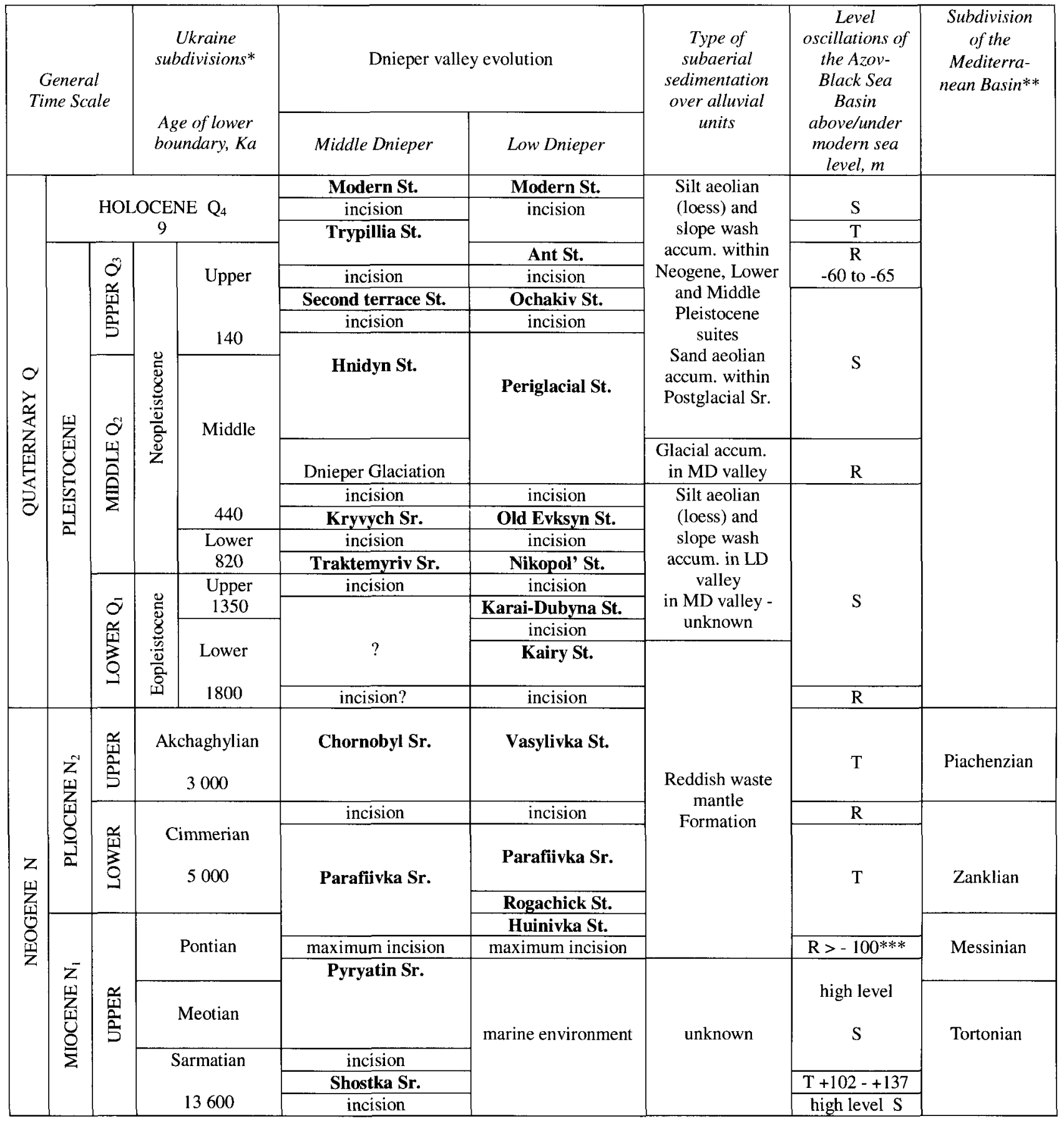

the alluvium of the Khadzhybey Terrace of the Dniester River.

The subassemblage of small mammals of the Karai-Dubyna locality (Fig. 6, exposure 29) occupies a transitional position between the Tamanian and
Tyraspol' faunal assemblages. The site is characterized by the domination of $P$. pannonicus transylvanicus, Microtus hintoni-gregaloides, Pallasiinus protoeconomys, Cricetus praeglacialis etc. On the basis of this mammal subassemblage the deposits of the Karai-Dubyna 

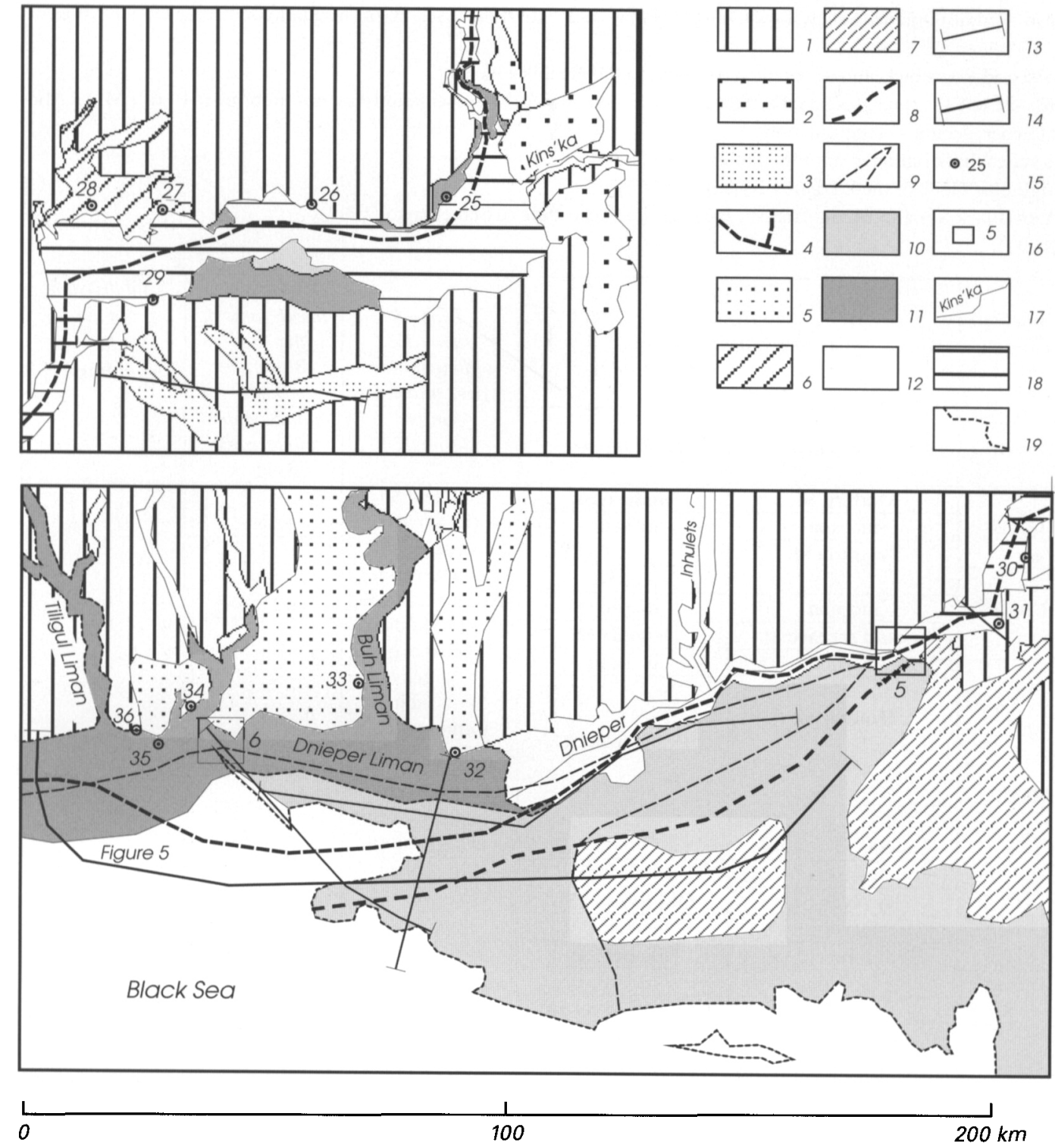

Fig. 6. Map of the alluvial suites and series distribution within the Lower Dnieper Valley

1 - plateau; 2 - Miocene-Pliocene unstratified series; 3 - Hunivka Series; 4 - talweg of maximum valley incision (presumably the end of the Late Miocene); 5 - Pliocene unstratified series of the South Buh Valley; 6 - Nicopol' Series; 7 - Kairy Series, 8 - west boundary of the buried Kairy Series; 9 - contours of the Old Evksyn Series beneath younger alluvial series; 10 - combined Ochakiv and Ant suites; 11 - Periglacial Suite; 12 - Modern Suite of the Dnieper Valley and also Quaternary unstratified alluvium of its tributaries; 13 - main geological profiles (numbered) used for the review (after Molyavko, 1960; Goretskiy, 1970) and new data; 14 - geological profiles used in the review; 15 - main exposures of alluvium (numbered); 16 - boreholes (numbered); 17 - rivers (named); 18 - Dnieper reservoirs; 19 - Black Sea coastline.

Main exposures: 25 - Lysa Hill, 26 - Mar'ivka open pit, 27 - Olexandrivka open pit, 28 - Olexiivka, 29 - Karai Dubina, 30 - Kairy, 31 - Vasylivka, 32 - Stanislav, 33 - Parutino, 34 - Chornomorka, 35 - Berezan' Island, 36 - Karabush Cape.

Boreholes: 5 - former Kakhovka Power Station building site, 6 - Ochakiv.

Suite are correlated with the alluvial deposits of the Mikhaylovka Terrace of the Dniester River. The Matuyama-Bruhnes boundary is fixed in the base of this alluvium. Later small-mammal remains (Fig. 6, exposures $27 \& 28$ ) have been revealed in the alluvium of the Nicopol' Suite (Lagurus transiens, Eolagurus luteus, Microtus gregaloides etc.). These species belong to the Kolkotovian subassemblage of the Tyraspol' faunal assemblage. The mollusc remains from the alluvium of the Nicopol' Suite (Unio tiraspolitanus, Vi- viparus tiraspolitanus etc.) belong to the Kolkotovian subassemblage too. These faunal data permit unequivcal correlation of the Nicopol' Suite of the Dnieper with the Kolkotovian Suite of the Dniester.

The most numerous finds of mammals and molluscs are from the deposits of the Kryvych Series. The mammals, which belong to the Singil' assemblage, are: Elephas primigenius trogontheri and Bison priscus longicomis among the large mammals and Lagurus lagurus, Microtus oeconomus ratticepoides, $M$. arvalinus 
Table 3 Paleontological data from alluvial deposits of the Middle-Lower Dnieper Valley ${ }^{\star}$ For position of the sites, see figs 2 and 5 .

\begin{tabular}{|c|c|c|c|c|}
\hline Series, suite & Site* & References & $\begin{array}{l}\text { Fauna } \\
\text { (mammals \& } \\
\text { molluscs) }\end{array}$ & $\begin{array}{l}\text { Faunal composition } \\
\text { (index and dominated species) }\end{array}$ \\
\hline Kairy & Kairy & Rekovets, 1994 & mammals & $\begin{array}{l}\text { Elephas meridionalis, Equus stenonis; } \\
\text { Spermophilus nogaici, Sicista vinogradovi, } \\
\text { Cricetus nannus, Villanyia fejervaryi, } \\
\text { Lagurodon arankae, Prolagurus pannonicus, } \\
\text { Mimomys intermedius, } \\
\text { Allophaiomys pliocaenicus }\end{array}$ \\
\hline Karai-Dubyna & Karai-Dubyna & $\begin{array}{l}\text { Markova, 1982; } \\
\text { Rekovets, } 1994\end{array}$ & mammals & $\begin{array}{l}\text { Apodemus sylvaticus, } \text { A. flavicolis, } \\
\text { Allocricetus bursae, Cricetus praeglacialis, } \\
\text { Clethrionomys glareolus, Mimomys pusillus, } \\
\text { Microtus hintoni-gregaloides, } \\
\text { M. protoeconomus }\end{array}$ \\
\hline Traktemyriv & Kaniv & $\begin{array}{l}\text { Gozhik, Lavrushyn, } \\
\text { Chugynnyi, } 1976\end{array}$ & molluscs & $\begin{array}{l}\text { Unio pseudochasaricus, } \\
\text { Crassiana pseudolitoralis }\end{array}$ \\
\hline Nikopol' & Olexiivka & Gozhik, 1992 & molluscs & $\begin{array}{l}\text { Viviparus pseudoachatinoides, } \\
\text { V. tiraspolitanus, Unio tiraspolitanus }\end{array}$ \\
\hline Nikopol' & Olexandrivka open pit & Gozhik, 1992 & molluscs & $\begin{array}{l}\text { Unio pseudochasaricus, } \\
\text { U.ex gr.tiraspolitanus, } \\
\text { Viviparus pseuidoachatinoides }\end{array}$ \\
\hline Nikopol' & Mar'ivka open pit & Goretskiy, 1970 & $\begin{array}{l}\text { mammals, } \\
\text { molluscs }\end{array}$ & $\begin{array}{l}\text { Elephas primigenius trogontherii, } \\
\text { Equus caballus, Bison priscus longicornis; } \\
\text { Viviparus diluvianus crassus, V. zickendrathi, } \\
\text { Crassiana crassa }\end{array}$ \\
\hline Kryvych & Matviivka & Rekovets, 1994 & mammals & $\begin{array}{l}\text { Arvicola chosaricus, Microtus gregalis, } \\
\text { Lagurus lagurus }\end{array}$ \\
\hline Kryvych & Chyhyryn & Rekovets, 1994 & mammals & $\begin{array}{l}\text { Arvicola mosbachensis, Eolagurus luteus, } \\
\text { Microtus arvalis }\end{array}$ \\
\hline Kryvych & Taburyshche & Goretskiy, 1970 & molluses & $\begin{array}{l}\text { Paludina diluviana, P. zickendrathi, } \\
\text { Fagotia esperi, Valvata piscinalis, } \\
\text { Lithoglyphus naticoides, Planorbis planorbis, } \\
\text { Gyraulus albus }\end{array}$ \\
\hline Kryvych & Pyvykha & $\begin{array}{l}\text { Gozhik, Lavrushyn, } \\
\text { Chugynnyi, } 1976\end{array}$ & molluscs & $\begin{array}{l}\text { Corbicula fluminalis, C. cov., } \\
\text { Viviparus diluvianus crassus, V. sokolovi, } \\
\text { Theodoxus serratiliformis }\end{array}$ \\
\hline Kryvych & Hun'ky & Rekovets, 1994 & mammals & $\begin{array}{l}\text { Cricetus praeglacialis, Arvicola mosbachensis, } \\
\text { Microtus gregalis, } M \text {. oeconomus, } M \text {. arvalis }\end{array}$ \\
\hline Kryvych & Hun'ky & Gozhik, 1992 & molluscs & $\begin{array}{l}\text { Unio tiraspolitanus, U. pseudochasaricus, } \\
\text { Viviparus sokolovi, Fagotia esperi }\end{array}$ \\
\hline Ant & Ochakiv & Gozhik, 1989 & molluses & $\begin{array}{l}\text { Viviparus ater, } V \text { sokolovi, Crassiana crassa, } \\
\text { Fagotia esperi, Theodoxus fluviatilis }\end{array}$ \\
\hline $\begin{array}{l}\text { Second Terrace } \\
\text { Trypiilia }\end{array}$ & Kaniv & Svistun, Lomaev, 1967 & mammals & $\begin{array}{l}\text { Coelodonta antiquitalis, Megaloceros } \\
\text { gigantheus ruffi, Cervus elaphus, Capreolus } \\
\text { capreolus, Rangifer tarandus, Bison priscus, } \\
\text { Mammuthus primigenius }\end{array}$ \\
\hline $\begin{array}{l}\text { Second Terrace } \\
\text { Trypilia }\end{array}$ & Taburyshche & Goretskiy, 1970 & molluscs & $\begin{array}{l}\text { Paludina diluviana, } P \text { zickendrathi, } \\
\text { Fagotia esperi, Valvata naticina, Lithoglyphus } \\
\text { naticoides, Planorbis gredleri, Dreissena } \\
\text { polymorpha }\end{array}$ \\
\hline
\end{tabular}




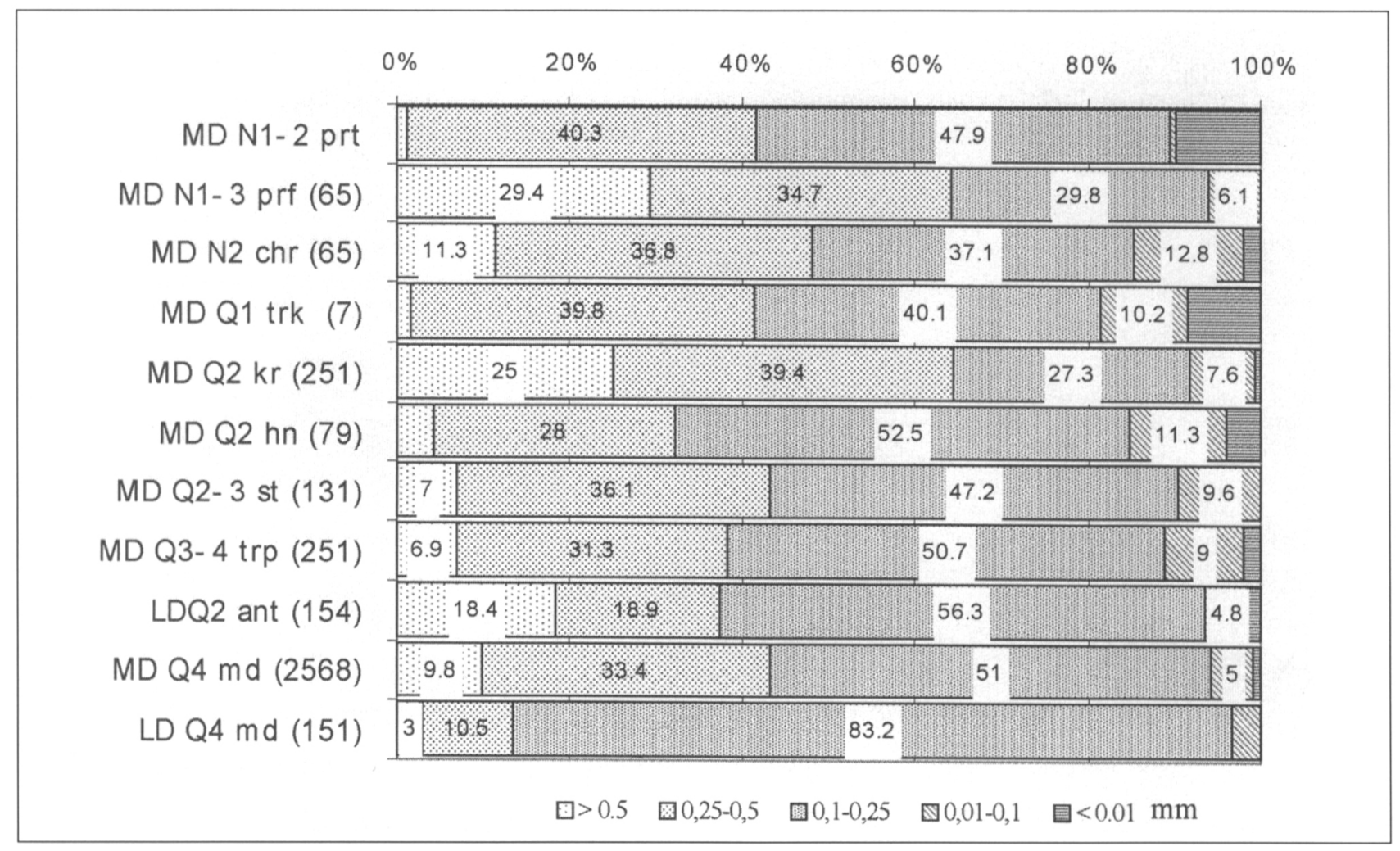

Fig. 7. Summarized particle-size distribution of the channel alluvial facies of the Dnieper Valley suites and series of different ages. Based on Goretskiy (1970), Barshchevskiy (1977) and new data.

MD - Middle Dnieper valley, LD - Lower Dnieper Valley.

Stratigraphy: N1 - Miocene, N2 - Pliocene, Q1 - Lower Pleistocene, Q2 - Middle Pleistocene, Q2-3 - Middle-Upper Pleistocene, Q3-4 Upper Pleistocene - Holocene, Q4 - Holocene.

prt - Pyriatin Series, prf - Parafiivka Series, chr - Chornobyl' Series, trk - Traktemyriv Series, kr - Kryvych Series, hn - Hnidyn Suite, st Second Terrace Suite, trp - Trypillia Suite, ant - Ant Suite, md - Modern Suite.

Number of determinations in brackets.

etc. among the small ones. The remains of small mammals from the Old Evksyn marine deposits of the Black Sea also belong to the Syngil' assemblage. They are correlated with sediments representing the Holsteinian transgression. The age equivalence of the Lower Kryvch and Old Evksyn suites is confirmed by freshwater molluscan faunas. The finds of Corbicula fluminalis and C. cor from the Middle Dnieper area (Fig. 2, exposure 18) are especially interesting. They are identical to finds from the Old Evksyn deposits. The remains from the Upper Kkryvych Suite (Fig. 2, exposure 22) belong to the Hazarian faunal assemblage (Spermophilus suslicus, Arvicola chosaricus, Microtus gregalis etc.). This alluvium corresponds to the so-called 'paludine sands' of Pivikha Hill (Fig. 2, exposure 18).

Small mammals from the suite of the 2nd terrace of the Dnieper River belong to the Shcurlatovian faunal assemblage and correspond to the Last Interglacial.

The numerous finds from the alluvium of the Trypillia Suite and from coeval subaerial deposits belong to the Upper Palaeolithic faunal assemblage of mammals.
There have also been numerous studies of pollen, plant macrofossils and ostracods (Goretskiy, 1970; Gubonina, 1980; Dykan', 1999), which have provided data predominantly of value for palaeogeographical reconstruction.

There are no reliable absolute dates from the alluvial deposits. The glacial deposits of the Dnieper Horizon (260-310 Ka) have been dated by Polish specialists using the TL method (Shelkoplias et al., 1985) and radiocarbon dates (11.2-12.7 Ka) have been obtained from the New Evksyn mud (Gozhik \& Novosel'skiy, 1989).

Archaeological dating evidence comes from the Kyrilivs'ka Upper Palaeolithic Site at Kiev, which occurred at the base of the 2nd Terrace Suite (Pidoplichko, 1969). Many sites of the same archaeological age are known from the basins of the Dnieper, Don and Dniester rivers, always topographically associated with the 2nd terrace above the floodplain. They have yielded radiocarbon dates within the range $29-23 \mathrm{Ka}$ (Ivanova, 1982). Mesolithic sites occur predominantly around Polissia (Isaenko, 1976) and Kiev (Kondu- 
for, 1982), within the highest levels of the 1st Terrace, and their absence within lower levels provides evidence that the Modern Suite began to form during the Mesolithic period or afterwards.

In some sections (Fig. 2, exposure 24; Fig. 6, exposure 31) loess-like subaerial deposits with buried soil horizons overlap the alluvium. The stratigraphy of this subaerial series has been established with reference to palaeopedological, mineralogical, palaeomagnetic, pollen and spore analyses and others (Veklich, 1968; Veklich and Sirenko, 1976). Macroscopic features allow correlation of most sites with the established stratigraphy. Thus, the age of the lowest horizon of the subaerial series at each site provides an indication of the upper stratigraphical boundary of the underlying alluvium. The authors consider this method to be subsidiary to those of direct dating of the alluvial deposits.

\section{Conclusion}

Some elements of the Dnieper Valley fluvial archive can be used for stratigraphical and palaeogeographical correlation. The complex of facies of the alluvial suites and the geomorphological features of the Dnieper Valley cited above provide the main grounds for correlation with the adjacent basins of the Don and Volga rivers, which are situated in the similar tectonic setting of the East European Platform. More distant correlation with various rivers can be carried out through comparison of mammalian and freshwater molluscan assemblages. It is also possible to achieve correlation with reference to global events such as glaciations and marine transgressions and/or regressions. The maximum incision of the valleys of the south periphery of the East European Platform, including the Dnieper, occurred in the Late Pontian (Late Messinian) in association with the sharp fall in sea-level in the Azov-Pontian and Mediterranean basins (Moliavko, 1960; Semenenko, 1992). Terrigenous deposits accumulated at this time on the continental slope of the Black Sea Depression (Kenneth \& Jiovanoli, 1979). Diatoms of Pontian and Cimmerian age are found in the overlying pelagic deposits, and the lower boundary of the Gilbert palaeomagnetic epoch is established $1 \mathrm{~m}$ above its base. Equivalent maximum incisions can be identified in the basins of the Black Sea and Mediterranean Sea. In the Dnieper Valley an important incision is seen at the end of the Late Pleistocene, corresponding to the Last European Glaciation. An Early Pleistocene incision, also caused by eustatic sea-level decline, may have occurred, but is questionable.

Reliable correlation has been established between the glacial deposits of the Dnieper Glaciation and the Odra and Saale glaciations of Central and Western Europe (Matoshko \& Chuhunnyi, 1993). The Hnydin and Periglacial suites, the formation of which was directly associated with the Dnieper Glaciation, can thus be correlated with analogous formations in the aforementioned areas.

The records of the Dnieper fluvial archive are of varying quality. Only certain chronostratigraphical stages are represented; others must be missing because of hiatuses. Dating of the alluvial units is the weakest point of the archive, with more dates badly needed as well as a re-evaluation of existing ones. The authors intend to continue their work, building upon the framework of the Dnieper fluvial archive. The interaction of tectonic structures, climate-hydrological changes, transgressive-regressive rhythms and sealevel oscillations, both within the inland marine basins and the global ocean, the direct and indirect influence of the continental glaciations as well as Coriolis Force effect will all be taken into consideration.

\section{Acknowledgements}

The authors thank Yu.G. Chugunny for fruitful ideas and endless discussion; Yu. Bredis, R.P. Bukatchuk and N.A. Partsevskiy - for data processing; Al. A. Matoshko and An. A.Matoshko for preparing the figures. Peter Allen, David Bridgland, Vicki Innes \& Danielle Schreve are thanked for helping edit the final text and for English language correction.

This paper represents a contribution to IGCP449: 'Global Correlation of Late Cenozoic Fluvial Deposits’.

\section{References}

Balandin, Yu.G. \& Arbuzova L.S.,1984. Subaeral'nyi otlozheniya na poberezhii i shel'fe zapadnoy chasti Chornogo morya, ih geneticheskaya tipizaciya i korellyaciya. In: Alekseyev, A.A. et al., (eds): Vozrast i genezis pereuglubleniy na shel'fah $\mathrm{i}$ istoriya rechnyh dolin. Nauka (Moscow): 51-59 (in Russian).

Bondarchuk, V.G. (Ed.), 1975. Stratygraphiya URSR. (Vol. 10). Neogen. Naukova dumka (Kyiv): 271 pp. (in Ukrainian).

Barshchevskiy, N.Eu., 1977. Stroeniye chetvertichnogo pokrova i istoriya chetvertichnogo osadkonakopleniya na territorii Kievskogo Prydneproviya. PhD thesis. Institute of Geological Sciences NAN of Ukraine (Kyiv): $161 \mathrm{pp}$. (in Russian).

Dmitriev, N.I., 1936. Rel'ief USSR (geomorfologicheskiy ocherk). Izdatel'stvo Khar'kovskogo universyteta (Kharkiv): 250 pp. (in Russian).

Dykan', N.I., 1999. Ostrakody rodyn Cypridae ta Eucandonidae iz aluvial'nykh pleistotsenovykh vidkladiv Ukrainy. Dopovidi natsional'noi akademii nauk Ukrainy 1: 120-127 (in Ukrainian).

Glushkov, B.V., 1985. Osobennosti stroyeniya Voronezhskoy flyuvioglyatsialnoy gryady. In: Krayevye obrazovaniya materikovykh 
oledeneniy. Nauka (Moscow): 120-121 (in Russian).

Goyzhevskiy, A.A. (Ed.), 1977. Geologicheskaya karta Ukrainskoy SSR i Moldavskoy SSR. Ministerstvo geologii USSR (Kyiv): 4 pp. (in Russian).

Golubitskaya, A.A., 1973. Verchnemiotsen-pliotsenovy i belovezhsko-likhvinskiy alluvialnye kompleksy $\mathrm{v}$ basseyne r.Ros'. In: Bondarchuk, V.G. (ed.): O nizhney granitse chetvertichnogo perioda. Naukova dumka (Kiev): 76-84 (in Russian).

Goretskiy, G.I., 1966. Formirovaniye doliny r.Volgi v rannem i srednem antropogene. Allyuviy Pra-Volgi. Nauka (Moscow): 412 pp. (in Russian).

Goretskiy, G.I., 1970. Allyuvialnaya letopis' velikogo pra-Dnepra. Nauka (Moscow): 491 pp. (in Russian).

Gozhik, P.F., 1982. Stroenie i usloviya formirovaniya pozdnepleystotsenovogo allyuviya $\mathrm{v}$ nizovyakh rek Prichernomorya. In: Materialy po izucheniyu chetvertichnogo perioda na territorii Ukrainy. Naukova dumka (Kyiv): 132-138 (in Russian).

Gozhik, P.F., 1992. Presnovodnye mollusci i korrelyatsia verkhnekajnozojskikh allyuvialnykh otlozhenij yuga VostochnoYevropejskoj platformy. Doctor thesis. Institute of Geological Sciences NAS of Ukraine (Kyiv): 287 pp. (in Russian).

Gozhik, P.F., Lavrushyn, Yu.A. \& Chuhunnyi, Yu.G.,1976. Glyatsiodislokatsii gory Pivikhi. Naukova dumka (Kyiv): 50 pp. (in Russian)

Gozhik, P.F., Chugunnyi Yu.G. \& Mel'nyk V.I., 1976. Putevoditel' VIII Mezhdunarodnogo simposiuma po lyessovym porodam. Naukova dumka (Kiev): 71 pp. (in Russian).

Gozhik, P.F. \& Kochubey, N.I., 1981. O vydelenii novogo stratigraphicheskogo gorizonta $\mathrm{v}$ verkhnem pleistotsene Prichernomorya. In: Stroyenie i voprosy korrelyatsii chetvertichnykh otlozheniy Ukrainy. Naukova dumka (Kiev): 125-131 (in Russian).

Gozhik, P.F. \& Novosel'skiy, F.A., 1989. Geologicheskiye usloviya stroitelstva Dneprovsko-Bugskogo gidrouzla. Naukova dumka (Kiev): 120 pp. (in Russian).

Gubonina, Z.P., 1980. Palinologicheskaya kharakteristika podmorennykh otlozheniy v basseyne Dnepra (po dannym razreza Gun'ki). In: Vozrast i rasprosranenie maksimal'nogo oledeneniya Vostochnoy Evropy. Nauka (Moscow): 153-168 (in Russian).

Isaenko, V.F., 1976. Neolit Pripyatskogo Polessiya. Nauka i tehnika (Minsk): 128 pp. (in Russian).

Ivanova, I.K., 1982. Iskopaemyi chelovek i yego kul'tura. In: Shantser, Ey.V. (ed.): Stratigraphiya SSSR. Chetvertichnaya sistema. Nauka (Moscow): 382-412 (in Russian).

Kenneth, J. \& Jiovanoli, F, 1979. Messinian event in the Black Sea. Palaeogeography, Palaeoclimatology, Palaeoecology 29: 75-93.

Kondufor, Yu.Yu. (ed.), 1982. Drevniy i srednevekovyi Kiev (Vol. 1).Naukova dumka (Kiev): 408 pp. (in Russian).

Lavrushyn, Yu.A., 1963. Allyuviu ravninnykh rek subarcticheskogo poyasa i periglyatsialnykh oblastey materikovykh oledeneniy. Izdatelstvo Akademii nauk SSSR (Moscow): 268 pp. (in Russian).

Lavrushyn, Yu.A. \& Chuhunnyi, Yu.G., 1982. Kanevskiye glyatsiodislokatsii. Nauka (Moscow): 104 pp. (in Russian).

Lazarenko, A.A., 1964. Litologiya allyuviya ravninnyh rek gumidnoi zony (na primere Dnepra, Desny, Oki). Nauka (Moscow): 236 pp. (in Russian).

Lepikash, I.A., 1938. Gorishnio-pliotsenovi poklady v raioni Nokopolia-Zaporizhzhia. Zhurnal geologo-geographichnogo tsyklu vydavnytstva Ukrains'koii akademii nauk, 4(8): 127-158 (in Ukrainian).

Makarenko, D.Yu. (ed.), 1987. Stratigraphicheskaya shema palaeogenovyh otlozheniy Ukrainy: (Unificirovannaya). Naukova dumka (Kiev): 114 pp. (in Russian).

Markova, A.K., 1982. Pleystotsenovye gryzuny Russkoy ravniny (ikh znacheniye dlya palaeogeographii i stratigraphii). Nauka
(Moscow): 183 pp. (in Russian)

Matoshko, A.V., 1995. Tyrizaciya i raionirovaniye osadochnogo chehla Chernobyl'skoy zony otchuzhdeniya dlya gidrogeologicheskogo monitoringa. Problemy Chornobyl's'koyi zony vidchuzhennya, 4: 95-108 (in Russian).

Matoshko, A.V. \& Chuhynnyi, Yu.G., 1993. Dneprovskoye oledeneniye territorii Ukrainy. Naukova dumka (Kiev): 191 pp. (in Russian).

Matsui, V.M., Mos'kina, O.D. \& Moskalenko, L.G., 1993. Novye dannye o stratigraphii pliotsena levoberezhya Srednego Dnepra. Doklady akademii nauk Ukrainy, 5: 100-104 (in Russian).

Matviishina, Zh.N. \& Vozgrin, B.D., 1991. Palaeogeographicheskiyi eskizy pozdnekainozoiskoy prirody basseina verhnyih techeniy rek Oster i Udai. In: Shnyukov, Eu.F. (Ed.): Litologiya osadochnogo chehla USSR (palaeogeographicheskiye aspecty), Naukova dumka (Kiev): 104-1 10 (in Russian).

Mel'nyk, M.O., 1928. Pro naslidky poperednikh doslidiv chetvertynnykh pidmorennykh piskiv v raioni Kanivs'kykh dyslokatsii. Vicnyk Ukrains'koho viddilu geologichnoii komisii, 11: 107-115 (in Ukrainian).

Miall, A.D., 1978. Fluvial sedimentology: An historical review. In: Miall, A.D. (Ed.): Fluvial Sedimentology. Canadian Soc. of Petrol. Geol. Memoir 5: 1-47.

Moliavko, G.I., 1960. Neogen pivdnya Ukrainy. Vudsvnytstvo akademii nauk Ukrains'koii RSR (Kyiv): 208 pp. (in Ukrainian).

Motuz, V.M., 1972. Nekotorye osobennosti stroeniya i veshchestvennogo sostava allyuviya raznovozrastnykh terras doliny Dnepra v predelakh BSSR. In: Voprosy geologii antropogena. Nedra (Moscow): 70-85 (in Russian).

Nazarenko, D.P., 1968. Geomorphologicheskaya karta $i$ istoriya formirovaniya neogenovyh $i$ antropogenovyh teras levoberezhiya USSR. Materialy Kharkovskogo otdela geographicheskogo obschestva Ukrainy, 6: 44-51 (in Russian).

Pidoplichko, I.G., 1969. Pozdnepalaeoliticheskiye zhylishcha iz kostey mamonta. Naukova dumka (Kiev): 163 pp. (in Russian).

Rekovets, L.I., 1994. Melkiye mlekopitayushchiye antropogena yuga Vostochnoy Yevropy. Naukova dumka (Kiev): 371 pp. (in Russian).

Reading, H.G., 1986. Sedimentary Environments and Facies. $2^{\text {nd }}$ Ed. Blackwell Scientific Publications (Oxford): 616 pp.

Shantser, Ye.V., 1961. Alluviy ravninnyh rek umerennogo poyasa $\mathrm{i}$ yego znacheniye dlya poznaniya zakonomernostey stroeniya $i$ formirovaniya alluvial'n'h svit. Trudy GIN AN SSSR, seriya gelogiya, vypusk 135, 55: 274 pp. (in Russian).

Semenenko, V.N., 1992. Denudatsionnye neogenovye poverkhnosti Prichernomorskoi vpadiny i Ukrainskogo shchita. Doklady akademii nauk Ukrainy, 11: 108-111 (in Russian).

Sobolev, D.N., 1938. O neogenovykh i chetvertychnykh terrasakh Ukrainy. Sovetskaya Geologiya, 6: 24-32 (in Russian).

Svistun, V.I. \& Lomayev, A.A., 1967. O geologicheskom vozraste iskopayemykh kostey mlekopitayushchikh iz rayona Kanevskoy GES. Vestnik zoologii, 3: 77-80 (in Russian).

Veklich, M.F., 1968. Stratigraphiya lyessovoy formatsii Ukrainy i sosednikh stran. Naukova dumka (Kiev): 238 pp. (in Russian).

Veklich, M.F. \& Dubniak, V.O., 1975. Palaeogeografichni etapy utvorennia teras Seredniogo Dnipra. In: Problemy geographichnoi nauky v URSR. Naukova dumka (Kyiv): 74-86.

Veklich, M.F. \& Sirenko, N.O., 1976. Pliotsen i pleistosen levoberezhya Nizhnego Dnepra i ravninnogo Kryma. Naukova dumka (Kiev): 185 pp. (in Russian).

Volkov, N.G. \& Sokolovskiy, I.L., 1976. Osnovnye problemy geomorphologii levoberezhya srednego Dnepra. Naukova dumka (Kiev): 135 pp. (in Russian).

Vorona, V.A., 1969. Verkhnepliotsenovye ozyerno-allyuvialnye ot- 
lozheniya levoberezhya Srednego Prydneprovya. In: Materialy po chetvertichnomu periodu Ukrainy. Naukova dumka (Kiev): 100113 (in Russian).

Yes'kov, B.G., 1977. Inzhenerno-geologicheskiye svoystva allyuviya Srednego Dnepra. Naukova dumka (Kiev): 196 pp. (in Russian).
Yes'kov, B.G., 1983. Sostav i svoystva rechnykh peskov v kososloistykh seriyakh. Institut geologicheskikh nauk (Kiev): 52 pp. (in Russian).

Zamoriy, P.K., 1961. Chetvertynni vidklady Ukrains'koii RSR. Vudvnytstvo kyivs'kogo universytetu (Kyiv): 549 pp. (in Ukrainian). 